\title{
Mathematics Teachers' Pedagogical Competence: How is the Attitude of the Mathematics Teachers in Teaching?
}

\author{
Fitri Ayu Ningtiyas \\ Postgraduate Mathematics Education Program, \\ Yogyakarta State University, INDONESIA \\ fitri.ayu2016@student.uny.ac.id
}

\author{
Jailani \\ Department of Mathematics Education, Faculty of \\ Mathematics and Natural Science, Yogyakarta State \\ University, INDONESIA
}

\begin{abstract}
Pedagogical competence is the ability of teachers in managing to learn. This study was designed to review the pedagogical competence of high school math teachers and their attitudes in teaching. Pedagogical competence in this research will be reviewed from two aspects, that is knowledge aspect and skill aspect. Aspects of knowledge are measured using tests and skill aspects measured using questionnaires. Mathematics teachers' attitude is reviewed by observing during the learning process and using an instrument adapted from attitudes towards mathematical modeling inventory. The sample of this research is 6 mathematics teachers from 3 high senior school with a different category. Based on these findings, mathematics teachers' attitude in teaching accordance with their pedagogic competence and school characteristics also guarantee how teachers decide their learning process.
\end{abstract}

Keywords- Teachers Pedagogical Competencies, Teachers' Attitude.

\section{INTRODUCTION}

Teachers become one of the important elements of education. Teachers are people who are very influential in the teaching-learning process, their roles and responsibilities in education is very heavy and hard [1]. Teachers have a great influence and role during the learning process to achieve the goals of national education [2]. Teachers have an important contribution to determine students achievement, the combination of initial cognitive abilities and teachers affective will affect $65 \%$ of students achievement and if supported by the quality of learning, the combination will affect $90 \%$ of students achievement [3]. Therefore, teachers need to improve their knowledge and skills to improve and explore their teaching practices [4]. Furthermore, teachers should really bring their students to the objectives to be achieved. Teachers must be able to influence their students. Considering this description, it is important for teachers to be competent [1].

Teacher competence needs to be discussed deeply so that teachers' potential in teaching can be improved [4]. This competency should be owned by every teacher in order to achieve success in learning and teaching [5]. Therefore, teachers must be aware that the practice of teaching is complex and they have to understand that teaching occurs in certain circumstances and requires constant decision making [6]. Besides that, attitude is one of the primary watchdogs for mathematics teachers' professional classroom behavior and they profoundly impact on decision making in any mathematics classroom [7]. Teachers with positive attitudes towards the subject likewise stimulate favorable attitudes in their students [8]. Furthermore, teachers' attitudes towards mathematics affect students' attitudes and achievement. [9].

The teacher must be familiar with the pedagogical competency of their subject-matter. Otherwise, the teaching would be marked by inconsistencies and thereby leading students to virtually learn nothing from the lesson [6]. Competence is defined as the performance, condition, and standard required so that the competence is more than just a job description or work activity [10]. Competence is seen as an ability to apply knowledge and skills [11]. Competence is sufficient skill and understanding to do a certain kind of work satisfactorily [12]. Teacher competence influences a teacher's values, behaviors, communication, goals, and teaching practices [10]. Therefore, teaching competence is a set of teachers' abilities, knowledge, and beliefs and is also used to create an effective learning process [12]. In this case, competence can be discussed in many dimensions [4]. This research will be limited to the pedagogical competence of mathematics teachers and their attitude.

Teacher pedagogical competence is the ability of the teacher in managing learning which includes learning program planning, learning process management and assessment [1]. Teacher pedagogical knowledge encompasses all the cognitive knowledge necessary to create an effective learning and teaching environment [13]. The effect of enhancing teacher pedagogical skills is generated gradually toward students, whereas when teachers improve pedagogical skills, student achievement will also increase [14]. Pedagogical competencies consist of knowledge and skills; successful teaching depends on deep knowledge, links theory and 
research to teaching and learning, and uses knowledge and skills in a rational context. [15]. Pedagogical competence means the ability and willingness to apply the attitude, knowledge, and skills to create learning in the best way [16]. Pedagogical competence should absolutely be owned by each teacher in order to carry out the learning tasks so that they can do all the things well [5]. Because teachers with good pedagogical knowledge can understand students' difficulties in learning mathematics [6]. On the other hand, pedagogical competence means the ability of a person to use a combination of instructional materials such as books, articles, case examples, and technology such as software and hardware and knowledge, skills, and experience [17]. So that, implementation of teacher pedagogical competence can optimize the development of learners from many aspects (intellectual, emotional and moral aspects) [1]. Besides that, teacher attitude in mathematics is one of the important determinants of student attitudes and performance in that subject'[18]. The main source of negative learner attitudes toward mathematics as inappropriate teaching practices and teacher attitudes [19].

Attitudes are defined by as manners of acting, feeling, or thinking that show one's disposition or opinion. [20]. Attitude is a learned association between an object and the evaluation of this object [21]. Attitude learning thus involves a dynamic interaction with the environment, in which attitudes both guide approach and avoidance behaviors, and are updated by the feedback that such exploration provides [22]. attitudes are learned and predispose one towards action which may be either favorable or unfavorable with respect to a given object. [23]. Attitudes are comprised of an emotional reaction to an object, behavior towards an object, and beliefs about the object [24]. attitudes can be defined as a summary evaluation of an object [25]. Attitude is a disposition towards an aspect of mathematics that has been acquired by an individual through their belief and experiences but which could be changed [26]. Attitudes towards mathematics represent a like or dislike of the subject and they embrace beliefs, abilities, and views on the usefulness of mathematics [27]. In this respect, Attitudes towards mathematical modeling inventory (ATMMI) used to assess teachers attitude. The ATMMI contains four dimensions, namely value, enjoyment, self-confidence, and motivation [28].

Besides that, the physical environment influences how teachers work and how teachers feel about the space in which they must spend a major portion of their working time [29]. In the public schools, there are good and poor classroom physical environments. For teachers, the highly stressful work regimen of working with children would mandate that the physical environment of the classroom support and assist them in helping students learn and review of research provides a discussion of the findings of several studies in which the subject was the relationship between the school building or classroom condition and teacher attitudes [30]. As follow up, the purpose of this study is to review 6 mathematics teachers pedagogical competence from knowledge and skill aspects. The six teachers are selected from 3 schools with different categories (high, medium and low categories). Then, this study also wants to know how is this six teacher attitude in teaching.

\section{METHOD}

In this study, which is carried out to reveal the pedagogical competence of mathematics teachers and their attitude in the learning process, descriptive-qualitative research method was applied. Qualitative research is a research aimed to describe and analyze the phenomena of people individually or in groups. The research participants are six mathematics teachers in three Senior High Schools. These schools were selected from 53 schools that have been grouped into three categories, which is high, medium and low. School grouping was reviewed based on mathematics national examination and the categories were adopted from Widoyoko [31]. The reasons for choosing schools is that the researcher wants to review the difference between teacher's attitude in teaching from different school categories.

The method of choosing the participants is voluntary and random sampling. Therefore, we have 2 mathematics teachers from each category, that are $\mathrm{T} 1$ and $\mathrm{T} 2$ from the high category, T3 and T4 from the medium category, T5 and T6 from the low category.

The research data were collected by three tools of data collection, that are the test and questionnaire to measure the pedagogical competence of mathematics, especially test to measure knowledge aspect and questionnaire to measure skill aspect. To answer the research question about mathematics teachers'attitude, instrument hence known as the Attitudes towards mathematical modeling inventory (ATMMI) were used. Each state has set the Likert scale attached to it (e.g., strongly positive, positive, neutral, negative, and strongly negative) and the respondent must choose one for each item. All the instruments to be used are validated by an expert judgment to see their consistency. The dimensions and number of items in each instrument are presented in Table 1.

TABLE I. DIMENSION AND NUMBER OF ITEMS IN EACH INSTRUMENT

\begin{tabular}{|c|c|c|c|}
\hline Aspect & Instrument & Dimension & $\begin{array}{l}\mathrm{N} \text { of } \\
\text { item }\end{array}$ \\
\hline \multirow{12}{*}{ Pedagogical } & \multirow{6}{*}{ Test } & Learning theory & 2 \\
\hline & & Principle of learning & 2 \\
\hline & & Approach/strategy/method/technique & 2 \\
\hline & & $\begin{array}{c}\text { The principle of curriculum } \\
\text { development }\end{array}$ & 2 \\
\hline & & Assessment techniques & 2 \\
\hline & & Characters of Student & 4 \\
\hline & \multirow{6}{*}{ Questionnaire } & Understandig student characteristics & 11 \\
\hline & & Using learning resource & 3 \\
\hline & & Using technology & 7 \\
\hline & & Implementing learning & 11 \\
\hline & & Evaluating learning & 13 \\
\hline & & Applying method & 9 \\
\hline
\end{tabular}


TABLE I. CONT.

\begin{tabular}{|c|c|c|c|}
\hline \multirow{2}{*}{ Aspect } & \multirow{2}{*}{ Instrument } & Dimension & $\begin{array}{c}\text { N of } \\
\text { item }\end{array}$ \\
\hline & & Communicating & 15 \\
\hline \multirow{3}{*}{ Attitude } & \multirow{3}{*}{ Questionnaire } & Value & 10 \\
\cline { 3 - 4 } & & Enjoyment & 10 \\
\cline { 3 - 4 } & & Self-confidence & 15 \\
\cline { 3 - 4 } & & Motivation & 5 \\
\hline
\end{tabular}

The collected data will be analyzed using descriptive analysis based on the qualitative research method. Analysis of data includes phrases interpretation of findings obtained. To review mathematics teacher pedagogical competence and attitude in learning, the result of the test and instrument were interpreted into five categories that adopted from Widoyoko [31]. On the other hand, data collected from observing were analyzed using thematic analysis approach.

\section{RESULTS AND DISCUSSION}

Pedagogical competence of mathematics teachers viewed from the aspects of knowledge and skills can be seen in table 2. Determination category based on 5 levels of categories (very good, good, fair, poor, very poor) that adopted from Widoyoko [31].

TABLE II. PEDAGOGICAL COMPETENCY CATEGORIES OF TEACHERS

\begin{tabular}{|c|c|c|c|}
\hline Subject & $\begin{array}{c}\text { Knowledge } \\
\text { (Test) }\end{array}$ & $\begin{array}{c}\text { Skill } \\
\text { (Questionnaire) }\end{array}$ & Category \\
\hline$T_{9}$ & 100 & 413 & Good \\
\hline$T_{9}$ & 85.71 & 434 & Good \\
\hline$T_{9}$ & 85.71 & 421 & Good \\
\hline$T_{4}$ & 64.29 & 257 & Poor \\
\hline$T_{9}$ & 57.14 & 261 & Poor \\
\hline$T_{\text {要 }}$ & 35.71 & 281 & Poor \\
\hline
\end{tabular}

Table 2 shows that teachers $T_{1}$ and $T_{2}$ from high category have the good pedagogical competency, and $T_{3}$ from medium category also has good pedagogical competency. Meanwhile, a teacher $T_{4}$ from the medium category, $T_{5}$ and $T_{6}$ from low category have fair pedagogical competency. Based on observations, this condition can also occur because the completeness of facilities owned by schools with high categories can encourage pedagogical skills of mathematics teachers to be better. Meanwhile, on the other hand, low schools have limited school facilities. In addition, teachers who teach in schools with high categories presented the implementation of learning in line with the lesson plan.

The attitude of the teachers' teaching is measured using Attitudes Toward Mathematical Modeling Inventory (ATMMI) [28]. The attitude of the teachers' teaching is presented in table 3 . This instrument consists of 4 dimensions namely value, enjoyment, self-confidence, and motivation as follows.
TABLE III. CATEGORIES OF TEACHERS ATTITUDE

\begin{tabular}{|c|c|c|c|c|c|}
\hline \multirow[b]{2}{*}{ Subject } & \multicolumn{4}{|c|}{ Dimension } & \multirow[b]{2}{*}{ Category } \\
\hline & Value & Enjoyment & $\begin{array}{c}\text { Self- } \\
\text { confidence }\end{array}$ & Motivation & \\
\hline$T_{1}$ & 40 & 37 & 57 & 15 & Good \\
\hline$T_{\mathrm{g}}$ & 44 & 46 & 61 & 17 & Good \\
\hline$T_{\mathrm{S}}$ & 25 & 35 & 44 & 17 & Fair \\
\hline$T_{4}$ & 23 & 32 & 39 & 10 & Poor \\
\hline$T_{9}$ & 27 & 19 & 37 & 11 & Poor \\
\hline$T_{8}$ & 22 & 26 & 39 & 9 & Poor \\
\hline
\end{tabular}

Table 3 shows that teachers from high category have good teaching attitudes. Furthermore, a teacher who comes from a medium category has a teaching attitude with a fair category and the other one gets a poor category. While the others who come from schools with low category have the attitude of teaching with poor category too. Teachers in low categories also have low enjoyment and motivation in teaching. Based on observation, communication between teachers and students does not occur in two directions and some students do not pay attention to the learning process.

In addition, based on observation of mathematics teachers in schools with high categories have teaching attitude that can encourage student activeness in learning, putting ideas and asking questions. The lesson plan prepared by the teacher also matches with the conditions that occur in the classroom. These findings show that teachers who teach in schools from high categories have good pedagogical competence and attitudes. Based on these findings, the researcher suggests that teachers who teach in enough and less categories of schools to enrich knowledge and hone skills and train themselves to have a fun teaching attitude for students

\section{CONCLUSION}

Teachers who come from a school with high category (based on Mathematics National Examination's average) have good pedagogical competence and attitudes. A good national examination result was also encouraged by mathematics teacher pedagogical competence and their attitude. It is also influenced by school facilities because the school with high category has adequate facilities. Their attitude in teaching also makes students comfortable and eventually it can improve student achievement. Teachers from medium and low category get a poor category for pedagogical competence and attitude. Especially teachers with low category have low enjoyment and motivation. This condition effect poor teachers' attitude.

\section{REFERENCES}

[1] Akhyak, M. Idrus, and Y. A. Bakar, "Implementation of Teachers Pedagogy Competence to Optimizing Learners Development in Public Primary School in Indonesia", Int. J of Education and Research, vol. 1, no. 9, pp. 1-10, 2013.

[2] S. Salam, Proceeding the 4th SEA-DR, vol. 52, 2016, pp. 404-408

[3] B. S. Bloom, Human characteristics and school learning, Tokyo: McGraw-Hill, 1976, p. 169. 
[4] S. Kiymet, "Teachers' Competencies", Int. J. of Culture and Axiology, vol. 7, no. 1, p. 167, 2010.

[5] M. Rahman, "Professional Competence, Pedagogical Competence and the Performance of Junior High School of Science Teachers", J. of Edu. and Practice, vol. 5, no. 9, pp. 75-80, 2014.

[6] A. K. Tsafe, "A Critical Analysis of Universal Basic Education on Its Implementation So Far", Scientific J. of Pure and Applied Sciences, vol. 2, no. 1, pp. 35-41, 2013.

[7] G. J. Jacobs and R. Durandt, "Attitudes of pre-service mathematics teachers towards modeling: A South African inquiry", Eurasia J. Of Mathematics Science and Tech. Edu., vol. 13, no. 1, pp. 61-84, 2017.

[8] O. P. Yara, "Relationship between teachers' attitude and students' academic achievement in Mathematics in some selected Senior Secondary Schools in South-western Nigeria", European J. of Social Sciences, vol. 11, no. 3, pp. 364-369, 2009.

[9] G. Dobson, A guide to writing competency-based training materials, Melbourne: National Volunteer Skills Centre), 2003, pp. 5-82.

[10] M. Mulder, European Vocational Education and Training, Human Resource Development: Learning, Education and Training, Kogan Page 3, 2012, pp. 155-175.

[11] M. Saeed and K. Mahmood, "Assessing Competency of Pakistani Primary School Teacher in Mathematics, Science, and Pedagogy", The Int. J. of Edu. Management, vol. 16, no. 4, pp. 190-195, 2002.

[12] S. Guerriro, "Teachers' Pedagogical Knowledge and the Teaching Profession", (http://www.oecd.org/edu/ceri/Background_document_to_Symposium_I TEL-FINAL.pdf), 2016.

[13] R. J. Marzano and M. D. Toth, Teacher evaluation that makes a difference: A new model for teacher growth and student achievement, Virginia: ASCD, 2013, p. 14.

[14] A. Sahana, Int. J. of Commerce, Business and Management, vol. 4, no. 2, pp. 1150-1155, 2015.

[15] K. Apelgren and B. Giertzswedish, Perspective on pedagogical competence: Pedagogical competence - a key to pedagogical development and quality in higher education., Uppsala University: Division for Development of Teaching and Learning, 2010, pp. 25-40.

[16] S. Madhavaram and D. A. Laverie, "Developing Pedagogical Competence: Issues and Implications for Marketing Education”, J. of Marketing Education, vol. 20, no. 10, pp. 1-17, 2010.

[17] L. R. Aiken, Attitudes toward mathematics Review of Educational Research 40, pp. 551-596, 1970.
[18] S. Henderson and S. Rodrigues, "Scottish student primary teachers' levels of mathematics competence and confidence for teaching mathematics: some implications for national qualifications and initial teacher education", J. of Teaching: Int. research and pedagogy, vol. 34, no. 2, pp. 93-107, 2008

[19] R. A. Philipp, Mathematics teachers' beliefs and affect. In F.K. Lester, Jr. (Ed.), The second handbook of research on mathematics teaching and learning Reston, VA: National Council of Teachers of Mathematics; Charlotte, NC: Information Age Publishing, 2007, pp. 257-315.

[20] R. H. Fazio, Attitudes as object-evaluation associations: Determinants, consequences and correlates of attitude accessibility In Attitude strength: Antecedents and consequences, ed. R E Petty and J A Krosnick Mahwah, NJ: Lawrence Erlbaum, 1995, pp. 247-82.

[21] J. R. Eiser, R. H. Fazio, T. Stafford, and T. J. Prescott, "Connectionist simulation of attitude learning: Asymmetries in the acquisition of positive and negative evaluations", Personality and Social Psychology Bulletin, vol. 29, pp. 1221-35, 2003.

[22] G. Leder, Attitudes toward mathematics. In T. A. Romberg \& D. M Stewart (Eds.), The monitoring of school mathematics: Background papers Vol 2, Wisconsin: University of Wisconsin Press, 1987.

[23] D. W. Rajecki, Attitudes: Themes and Advances, Sunderland MA: Sinaur Associates, 1982.

[24] D. C. Bramlett and S. Herron, "A Study of African-American College Students' Attitudes towards Mathematics “, J. of Mathematical, 2009.

[25] B. A. Eshun, "Sex-differences in attitude of students towards Mathematics in secondary schools", Mathematics Connection, vol. 4, pp. $1-13,2004$.

[26] B. Schenkel, The impact of an attitude towards Mathematics on Mathematics performance Master's dissertation, USA: Ohio, 2009.

[27] J. W. Schackow, Examining the attitudes toward mathematics of preservice elementary school teachers enrolled in an introductory mathematics methods course and the experiences that have influenced the development of these attitudes Unpublished doctoral dissertation, University of South Florida, 2005.

[28] G. Kielhofner, A Model of Human Occupation: Theory and Application Lippincott, Williams, and Wilkins, Philadelphia: PA, 2002.

[29] G. I. Earthman and L. K. Lemasters, "Teacher Attitude About Classroom Condition", J. Of Educational Administration 47(3) pp 323$335,2009$.

[30] E. P. Widoyoko, Evaluasi Program Pembelajaran, Yogyakarta: Pustaka Pelajar, 2016, p. 238. 